\title{
Handwashing Behavior Using Soap, Physical Conditions of Cooking Food Storage and Deare Incidence
}

\author{
Tuhu Pinardi ${ }^{1 *}$, Suparji Suparji ${ }^{2}$ \\ ${ }^{1}$ Department of Environmental Health, Health Polytechnic of the Ministry of Health Surabaya, Surabaya, Indonesia; ${ }^{2}$ Department \\ of Midwifery, Health Polytechnic Ministry of Health Surabaya, Surabaya, Indonesia
}

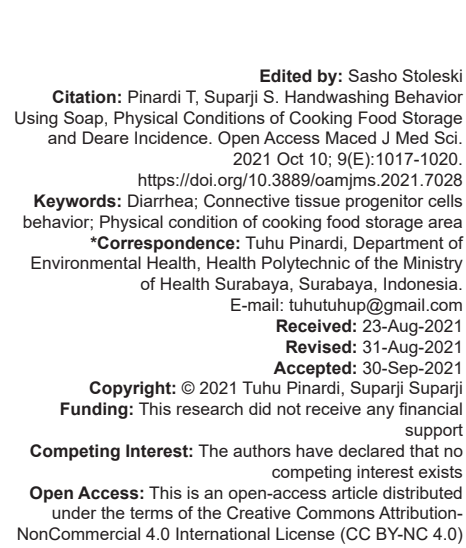

\section{Introduction}

Diarrhea is a condition in which a person defecates with a soft or liquid consistency, it can even be just water and the frequency is more frequent, usually three or more times a day [1]. Some of the causes of diarrhea include environmental sanitation conditions and Clean and Healthy Life Behavior. While clinically the causes of diarrhea can be grouped into six major groups, namely, infection, malabsorption, allergies, poisoning, immunization, deficiency, and other causes [1], [2].

The WHO report in 2009 stated that around 1.1 million children under 5 years of age died from diarrhea [2], [3]. Diarrhea is an endemic disease in Indonesia and is also a potential disease outbreak which is often accompanied by death [2]. In 2014, there were six outbreaks of diarrhea spread across five provinces, six districts/cities with 2549 patients with 29 deaths (case fatality ratio [CFR] 1.14\%). While, the target CFR in diarrhea outbreaks is expected to be $<1 \%$ [3]. Based on the 2013 RI Health Profile, the number of diarrhea outbreaks in East Java was 59 cases and the number of diarrhea cases that were handled was 672,700 cases [4]. Meanwhile, in 2014 cases of diarrhea were handled as many as $1,015,968$ cases [5]. From the results of the recapitulation of diarrhea data from the Magetan District Health Office, in 2014 there were 14,121 people with diarrhea and in 2015 there were 9823 people. Based on data from the Magetan District Health Office, the number of diarrhea sufferers in the working area of Parang Health Center ranks first as many as 782 people [6].

Efforts to control the incidence of diarrhea disease have been carried out through health promotion activities regarding environmental hygiene and promotion of clean and healthy living behavior (PHBS) in daily life at the individual, family, and community levels.

\section{Materials and Methods}

Method: This type of analytic research with Case-Control design [7]. The population of Pragak 
village is 2500 families. The sample is residents of Pragak Village, who suffer from diarrhea and do not suffer from diarrhea at the same time as many as 40 respondents, the sampling method is simple random sampling technique. The independent variable is the behavior of washing hands using soap, the physical condition of the cooking food storage area, the dependent variable is the incidence of deare. Data collection instruments are questionnaires and interview guidelines and observation sheets. Data analysis with Chi-square statistical test, the error rate is set $<0.05$.

\section{Results}

The results of the study on the behavior of washing hands using soap, the physical condition of the cooking food storage area and the incidence of deare are as follows:

\section{Research results data on handwashing behavior with soap with diarrhea incidence}

From the results of research conducted on 20 respondents who were sick and 20 respondents who were not sick, it was found that $13(65 \%)$ respondents who were sick had poor hand washing behavior with soap, while for respondents who were not sick with diarrhea $6(30 \%)$ respondents have bad hand washing behavior with soap. Based in Table 1 above, it can be seen that $p$-value $(0.027)<(0.05)$ which means that there is a relationship between hand washing behavior with soap and the incidence of diarrheal disease in Pragak Village, Parang District, Magetan Regency in 2016.

Table 1: Data on Handwashing Behavior with Soap with Diarrhea Incidence in Pragak Village, Parang District, Magetan Regency in 2016

\begin{tabular}{llllll}
\hline Hand washing behavior & \multicolumn{2}{l}{ Diarrhea incidence } & Total & p-value & OR \\
\cline { 2 - 3 } using soap & Diarrhea & Diarrhea & & & \\
\hline Bad & $13(68.42 \%)$ & $6(31.58 \%)$ & $19(100 \%)$ & 0.027 & 4.333 \\
Well & $7(33.33 \%)$ & $14(66.66 \%)$ & $21(100 \%)$ & & \\
Total & $20(100 \%)$ & $20(100 \%)$ & 100 & & \\
\hline
\end{tabular}

Based on the calculation of the Odds Ratio $(\mathrm{OR})$ it is known that $\mathrm{OR}(4.333)>1$, which means that respondents with poor handwashing behavior with soap have a 4.333 times greater chance of getting diarrhea compared to respondents with good behavior.

\section{Research result data about physical condition of cooking food storage place and diarrhea incidence}

From Table 2 above, it can be seen that $3(15 \%)$ respondents who were sick had poor physical conditions for storing cooked food, while for those who were not sick 5 (25\%) respondents had poor storage
Table 2: Data on the Physical Condition of Cooked Food Storage with Diarrhea Incidence in Pragak Village, Parang District, Magetan Regency in 2016

\begin{tabular}{llllll}
\hline \multirow{2}{*}{$\begin{array}{l}\text { Physical condition of } \\
\text { food storage cook }\end{array}$} & \multicolumn{2}{l}{ Diarrhea incidence } & Total & p-value & OR \\
\cline { 2 - 4 } & Diarrhea & Not Diarrhea & & & \\
\hline Bad & $3(37.5 \%)$ & $5(62.5 \%)$ & $8(100 \%)$ & 0.695 & 0.529 \\
Well & $17(53.13 \%)$ & $15(46.87)$ & $32(100 \%)$ & & \\
Total & $20(100 \%)$ & $20(100 \%)$ & $40(100 \%)$ & & \\
\hline
\end{tabular}

conditions for cooked food. Based on statistical tests, the results obtained $p$-value $(0.695)>0.05$, which means that there is no relationship between the condition of the storage area for cooked food and the incidence of diarrhea in Pragak Village, Parang District, Magetan Regency in 2016. Judging from the OR calculation, it is known that the OR $(0.529)<1$ which means the condition of the place Storage of cooked food is a protective factor against diarrheal diseases. Respondents with poor storage conditions for cooked food have a 0.529 times greater chance of developing diarrheal disease than respondents with good storage conditions for cooked food.

\section{Discussion}

\section{The relationship between handwashing behavior and diarrhea}

From the results of the Chi-square test, it can be seen that $p$-value $(0.027)<(0.05)$ which means there is a relationship between the behavior of washing hands with soap and the incidence of diarrheal disease. Hence, it can be said that hand washing behavior with soap is a supporting factor and can affect the occurrence of diarrheal disease in Pragak Village, Parang District, Magetan Regency in 2016. This is in line with the results of research conducted by Alif Nurul Rosyidah on students at SDN Ciputat 02 Jakarta which shows that from the results of statistical tests can be seen that there is a relationship between the behavior of washing hands with soap with the incidence of diarrheal disease p-value $(0.015)<(0.05)$ washing hands with soap in daily life [8], [9]. This is because most respondents do not know the important times to wash their hands with soap. [9]. In addition, the facilities or infrastructure owned by the respondents are limited. According to Green in Notoatmodjo's book, behavior is formed from predisposing factors (knowledge, attitudes, beliefs, beliefs, values, and so on), supporting factors (physical environment, availability or unavailability of health facilities or facilities such as health centers, medicines, etc.), latrines, and so on, driving factors (attitudes and behavior of health workers or other officers) [9].

Based on the OR calculation, it shows that the behavior of washing hands with soap is a risk factor for diarrheal disease with an OR (4.333) > 1 (95\% $\mathrm{Cl}: 1.15-16.323)$ which means that respondents with 
poor handwashing behavior have a 4,333 times greater chance of being affected. Diarrheal disease compared to respondents with good hand washing behavior. Based on the Indonesian Ministry of Health (2014), the level of effectiveness of washing hands with soap in reducing the number of diarrhea sufferers in percent by type of prevention innovation is $44 \%$. The behavior of washing hands with soap before or after carrying out activities is one of the efforts to avoid diarrheal diseases [3], [10]. The relationship between the physical condition of the cooking food storage area and diarrhea from the Chi-square test results can be seen that $p$-value $(0.429)>(0.05)$ which means that there is no relationship between the physical condition of the cooked food storage area and the incidence of diarrheal disease. It can be said that the physical condition of the cooking food storage area is not a supporting factor or does not affect the incidence of diarrheal disease in Pragak Village, Parang District, Magetan Regency in 2016. These results are in line with the results of research conducted by Ali Rosidi et al. on children at SDN Podo 2 Regency. Pekalongan with statistical test results $p$-value $(0.695)>(0.05)$ in the sense that there is no relationship between food sanitation and the incidence of diarrhea [2], [11]. In this case, most of the respondents who have been researched have made efforts to always cover cooked food and maintain the cleanliness of the cooking food storage area. Cooked food that is ready to be consumed is one of the factors that can cause diarrheal disease [11], [12], [13], [14]. Because cooked food is one of the preferred places for microorganisms to breed.

If the storage of cooked food is not handled properly and correctly, the possibility/risk of food contamination by bacteria (causing diarrhea) becomes greater. So that after eating these foods, they are most likely to experience diarrhea. According to the 2014 Directorate General of PPPL, flies often land in human and animal feces. When perched on food, flies attach human and animal waste to food and drinks that are not properly covered, which can cause diarrhea [11], [15], [16], [17]. Food and drinks that are not tightly closed, can also be exposed to air that contains germs and can cause diarrhea. Meanwhile, based on the calculation of the OR, it shows that the physical condition of the storage area for cooked food is a protective factor with OR $(0.529)<1(95 \% \mathrm{Cl}$ : 0.108-2.598) which means that respondents with poor physical condition of the storage area for cooked food are at 0.529 times greater risk of being affected. Diarrheal disease from respondents with good physical condition of cooking food storage. The Decree of the Minister of Health of the Republic of Indonesia 2003 concerning food and beverage hygiene is an effort to control the factors of food, people, places, and equipment that may cause disease or health problems [2], [10], [18], [19].

\section{Conclusion}

The behavior of washing hands with soap as a supporting factor for the occurrence of diarrheal disease in Pragak Village, Parang District, Magetan Regency. Bad hand washing behavior with soap has a 4.333 times greater chance of causing diarrheal disease than good hand washing behavior. The physical condition of the cooking food storage area is not proven to contribute to the incidence of diarrheal disease. The physical condition of the storage area for cooked food that is bad has a 0.529 times greater chance of causing disease compared to the physical condition of the place where the food is stored well.

The recommendation from this research is that there is a need to increase counseling activities about clean and healthy living behavior (PHBS) and counseling about diarrheal diseases which include modes of transmission, prevention, handling, and treatment. So that the degree of public health increases and it is hoped that the incidence of environmentalbased diseases, especially diarrhea, can decrease.

\section{Ethical clearance}

Ethical license is an approval from the Health Polytechnic Research Ethics Commission of the Ministry of Health Surabaya, this research does not use human and animal experiment objects, and it only carries out surveys.

\section{References}

1. Kemenkes RI. Pocket Book of Health Officers Cross Diarrhea (Buku Saku Petugas Kesehan Lintas Diare). Departemen Kesehatan RI, Ditjen PPPL, Jakarta; 2011.

2. Rosidi A, Handarsari E, Mahmudah M. The Relationship between Hand Washing and Food Sanitation Habits with the Incidence of Diarrhea in Podo 2 Elementary School Children, Kedungwuni District, Pekalongan Regency.(Hubungan Kebiasaan Cuci Tangan dan Sanitasi Makanan dengan Kejadian Diare pada Anak SD Negeri Podo 2 Kecamatan Kedungwuni Kabupaten Pekalongan). Indonesia: Semarang Universitas Muhammadiyah Semarang; 2010. https://doi.org/10.37036/ahnj.v2i1.42

3. Kemenkes RI. Indonesia Health Profile 2014 (Profil Kesehatan Indonesia Tahun 2014). Kementian Kesehatan RI. Jakarta: Sekjen Kemenkes RI; 2015. https://doi.org/10.32922/jkp.v8i1

4. Jatim D. Health Profile of East Java Province 2014. (Profil Kesehatan Provinsi Jawa Timur Tahun 2014). Surabaya: Dinas Kesehatan Provinsi Jawa Timur; 2014. https://doi.org/10.22435/ hsr.v19i2.5962.149-156

5. Jatim D. Health Profile of East Java Province 2015 (Profi Kesehatan Provinsi Jawa Timur Tahun 2015). Surabaya: Dinas Kesehatan Provinsi Jawa Timur; 2015. https://doi.org/10.22435/ hsr.v19i2.5962.149-156

6. Magetan DK. Health Profile of Magetan 2014. (Profil Kesehatan Kabupaten Magetan 2014). Magetan: Dinas Kesehatan 
Kabupaten Magetan; 2014. https://doi.org/10.36568/kesling. v16i2.825

7. Soekidjo N. Health Research Methodology. (Metodolog Penelitian Kesehatan). Jakarta: Rineka Cipta; 2005.

8. Retno P. The Relationship Between Drinking Water Supply and Sanitary Hygiene Behavior with Diarrhea in Post-Disaster Areas, Banyudono Village, Dukun District, Magelang Regency (Hubungan Antara Penyediaan Air Minum dan Perilaku Hygiene Sanitasi dengan Kejadian Diare di Daerah Paska Bencana Desa Banyudono Kecamatan Dukun Kabupaten Magelang). Semarang: Universitas Negeri; 2012. https://doi.org/10.24929/ fik.v9i2.784

9. Roya SC. Relationship between Clean Water Sanitation Facilities and Mother's Behavior on Diarrhea Incidence in Toddlers Age 10-59 Months in the Keranggan Health Center Area, Setu District, South Tangerang City, 2013. (Hubungan Sarana Sanitasi Air Bersih dan Perilaku Ibu Terhadap Kejadian Diare Pada Balita Umur 10-59 Bulan di Wilayah Puskesmas Keranggan Kecamatan Setu Kota Tangerang Selatan Tahun 2013). Jakarta: Universitas Islam Negeri Syarif Hidayatullah; 2014. https://doi.org/10.52118/edumasda.v2i2.18

10. Djarkoni IH, Lampus BS, Siagian IE, Kaunang WP, Palandeng HM. The relationship between handwashing with soap and Diarrhea at Sario Adventist elementary school, Manado city (Hubungan perilaku cuci tangan pakai sabun dengan kejadian diare di SD advent Sario Kota manado). J Kedokteran Topik. 2014;2(3):95-8. https://doi.org/10.33086/mtphj.v4i1.773

11. Sinthamurniwaty S. Risk Factors for Acute Diarrhea in Toddlers (Faktor-faktor Risiko Kejadian Diare Akut Pada Balita). Semarang: Universitas Diponegoro; 2006.

12. Cahyaningrum D. Risk Factors for Acute Diarrhea in Toddlers A Study on Diarrhea and its Risk Factors in Toddlers Age 1-5 Years in the Work Area of the Kalasan Health Center, Sleman, 2015. (Studi Tentang Diare Dan Faktor Resikonya Pada Balita Umur 1-5 Tahun Di Wilayah Kerja Puskesmas Kalasan Sleman, 2015); 2017. Available from: http://www.digilib.unisayogya. ac.id/386/1/naskah\%20publikasi\%20desi $\% 20 \% 281 \% 29$.pdf [Last accessed on 2017 Oct 30]. https://doi.org/10.31227/osf.io/ zqu5f

13. Fahrurazi F. Relationship between Knowledge and Behavior of Mother's Handwashing with Soap (CTPS) with the Incidence of Diarrhea in Toddlers in the Working Area of Kuin Raya Public Health Center, Banjarmasin City. Borneo (Hubungan Pengetahuan dan Perilaku Cuci tnagan Pakai Sabun (CTPS) Ibu dengan Kejadian Diare Pada Balita di Wilayah Kerja Puskesmas Kuin Raya Kota Banjarmasin. Kalimantan).
Indonesia: Universitas Islam Kalimantan; 2016. Available from: https://www.ojs.uniska-bjm.ac.id/index.php/ann/article/view/843 [Last accessed on 2017 Aug 13]. https://doi.org/10.14710/ jkli.19.1.7-15

14. Putri N. The Relationship of Ex-Breastfeeding with the Incidence of Diarrhea in Infants Age 6-12 Months at BPS Surami Bantul. Yogyakarta (Hubungan Pemberian Asi Eks Dengan Kejadian Diare Pada Bayi Umur 6-12 Bulan di BPS Surami Bantul. Yogyakarta). Indonesia: Universitas 'Aisyiyah Yogyakarta; 2016. Available from: http://www.digilib.unisayogya.ac.id/2198/1/ naskah\%20publikasi.pdf.pdf [Last accessed on 2017 Sep 17]. https://doi.org/10.21927/jnki.2016.4(2).84-89

15. Wulandary A. The Relationship between Environmental Factors and Sociodemographic Factors with the Incidence of Diarrhea in Children Under Five in Blimbing Village, Sambirejo District, Sragen Regency in 2009 (Hubungan Antara Faktor Lingkungan dan Faktor Sosiodemografi Dengan Kejadian Diare Pada Balita di desa Blimbing Kecamatan Sambirejo Kabupaten Sragen Tahun 2009). Surakarta: Universitas Muhammadiyah Surakarta; 2009. Available from: http://www.eprints.ums.ac.id/5960 [Last accessed on 2017 Oct 11]. https://doi.org/10.31227/osf.io/ q6xg8

16. Rompas M, Tuda J, Ponidjan T. The relationship between handwashing with soap behavior and the occurrence of diarrhea in school-age children in sd gmim dua, tareran district (Hubungan Antara Perilaku Cuci Tangan Pakai Sabun Dengan Terjadinya Diare Pada Anak Usia Sekolah di SD Gmim Dua Kecamatan Tareran). J Keperawatan. 2013;1(1):1-8. https://doi. org/10.33086/mtphj.v4i1.773

17. Kurniawati RD, Malik MI. The correlation between healthy latrines with the occurrence of diarrhea towards community in cicalengka kulon village, sub district of cicalengka, bandung regency. In: International Conference on Health and Well-Being (ICHWB); 2016. p. 153.

18. Sugiarto KT. The Relationship between Basic Home Sanitation Facilities and Habit of Washing Hands with Soap with Diarrhea Incidence in the Working Area of Miri Health Center, Sragen Regency (Hubungan Antara Sarana Sanitasi Dasar Rumah Dan Kebiasaan Cuci Tangan Pakai Sabun Dengan Kejadian Diare Di Wilayah Kerja Puskesmas Miri Kabupaten Sragen); 2016. https://doi.org/10.14710/jkli.19.1.7-15

19. Sudasman FH. Relationship of Ownership of Basic Sanitation Facilities, Personal Hygiene to History of Diseases Throughout Baleendah District (Hubungan Kepemilikan Sarana Sanitasi Dasartangga, Personal Hygiene Terhadap Riwayat Penyakit Sepanjang Aliran Kecamatan Baleendah), Jakarta; 2014. 